\title{
APPLICABILITY OF WAIVER, ESTOPPEL, AND LACHES DEFENSES TO PRIVATE SUITS UNDER THE SECURITIES ACT AND S.E.C. RULE 10B-5: DETERRENCE AND EQUITY IN BALANCE
}

T\#E Securities Act of $1933,{ }^{1}$ enacted to counteract widespread fraud in the securities industry, ${ }^{2}$ was structured to require complete disclosure of facts thought necessary to assure informed investing - to promote "truth in securities." 3 To insure this disclosure Congress did more than simply codify existing common law protections of defrauded investors; rather, the civil liabilities sections of the act were designed as in terrorem provisions. By making it easier for victims of fraud to recover, the act aimed at "terrorizing" issuers, underwriters, dealers, and other sellers into compliance with its disclosure requirements. ${ }^{4}$ Occasionally, defrauded investors, instead of relying on the protections afforded them in the 1933 act, have based their suits upon SEC rule 10b-5, ${ }^{5}$ promulgated under section 10 (b) of the Securities Exchange Act of 1934. In the last few years several cases ${ }^{6}$ under rule $10 \mathrm{~b}-5$ and the civil liability provisions of the 1933 act have allowed interposition of the defenses of waiver, estoppel, and laches in spite of the deterrent purpose of the act and in the absence of any mention of these common-law ${ }^{7}$ defenses on the face of

1. 48 Stat. 74 (1933), as amended, 15 U.S.C. $\$ \$ 77 a-77 a a ~(1958)$.

2. See generally H.R. REP. No. 85, 73d Cong., 1st Sess. 1-9 (1933).

3. See, e.g., id at 2; Dodd, How Not to Amend the Federal Securities Act - Fundamental Purpose Should Not Be Impaired, 20 A.B.A.J. 247-48 (1934); Legislation, 33 Colurr. L. Rev. 1220, 1223-24 (1933) ; 77 Cong. Rec. 2912 (1933) (remarks of Representative Mapes); Hearings on H.R. 4314 Before the House Committee on Interstate and Foreign Commerce, 73d Cong., 1st Sess. 40 (1933).

4. Douglas \& Bates, The Federal Securities Act of 1933, 43 YALE L.J. 171, 173-77 (1933), Shulman, Civil Liability and the Securities Act, 43 Y ALE L.J. 227 (1933); Feldman, The New Federal Securities Act, 14 B.U.L. Rev. 1, 20 (1934).

5. 17 C.F.R. \& 240-10b-5 (1949).

6. Straley v. Universal Uranium \& Milling Corp., 289 F.2d 370 (9th Cir. 1961), revcrsing 182 F. Supp. 940 (S.D. Cal. 1960), applying $\$ 12(1)$ of the 1933 act, allowed interposition of the estoppel and waiver defenses, but disallowed laches. On remand, the defenses were not established by the evidence, and the court of appeals affirmed. 312 F.2d 745 (9th Cir. 1962). Dale v. Rosenfeld, 229 F.2d 855 (2d Cir. 1956) (Section 12(2) case, estoppel and waiver allowed, laches not raised). Royal Air Properties, Inc. v. Smith, 312 F.2d 210 (9th Cir. 1962) (rule 10b-5 case, estoppel, waiver, and laches allowed). On remand, the trial court found that the defenses were not established by the evidence. Brief for Appellee, p. 5, Royal Air Properties, Inc. v. Smith, No. 19020, 9th Cir. 1964.

7. "Waiver" will be used to refer to the voluntary and intentional relinquishment of a legal right or claim; "estoppel" to refer to the denial of a plaintiff's assertion of a right, where he has made prior representations, reasonably and detrimentally relied upon by the defendant, which are inconsistent with the asserted right; and "laches" to refer to an unreasonable delay in asserting a right, to the disadvantage of the defendant. To the extent that other terms, such as ratification, abandonment, and acquiescence are used to embody these concepts, the discussion will include them.

Although some of these defenses trace their origin to courts of equity, the term "common-law defenses" will be used to include them, unless otherwise noted. 
these laws or in their legislative history. But while these cases have posed the issue of the applicability of the estoppel, waiver, and laches defenses under the 1933 act and rule $10 \mathrm{~b}-5$, they have failed adequately to recognize the possible conflict between the general in terrorem function of the act and the allowance of these defenses, which are normally available in civil actions to assure equitable treatment of the parties.

Examination of the civil liabilities provisions of the 1933 act, sections $11,^{8}$ $12(1),{ }^{9}$ and $12(2),{ }^{10}$ reveals a bifurcated approach to the problem of insuring dissemination of adequate information to investors: Sections 11 and 12(1) apply to the process by which newly issued securities reach the hands of ultimate investors; ${ }^{11}$ section $12(2)$, in effect, deals with transactions after initial distribution of the issue. ${ }^{12}$ Section $12(1)$ operates to implement disclosure in two ways. First, it imposes liability on any person in the initial chain of distribution ${ }^{13}$ of the issue who sells a security for which no registration statement is in effect with the SEC. ${ }^{14}$ Second, section $12(1)$ imposes liability on the same parties if they do not provide the buyer with a prospectus containing information identical to that in the registration statement. ${ }^{15}$ Section 11 complements section $12(1)$ by insuring the completeness and truth of those registration statements actually filed and in effect under the act. To effectuate

8. 48 Stat. 82 (1933), as amended, 15 U.S.C. § 77k (1958).

9. 48 Stat. 84 (1933), as amended, 15 U.S.C. $\$ 77 l(1)$ (1958).

10. 48 Stat. 84 (1933), as amended, 15 U.S.C. $\$ 77 l(2)$ (1958).

11. See notes 13 and 17 infra and accompanying text.

12. See note 18 infra and accompanying text.

13. The extensive exceptions of certain persons and transactions from the coverage of $\$ 12(1)$ indicate that it is concerned with the transactions by which the security is transmitted from the corporation through intermediate parties to investors. Exempted from $\$ 12(1)$ are (in simplified form): transactions by persons other than underwriters, issuers, and dealers as defined by the act; transactions by an issuer not involving any public offering; transactions by a dealer more than forty days after the securities were first offered to the public; brokers' transactions executed upon customers' orders on exchange or over-the-counter markets; issuance to present shareholders; and issuance to creditors pursuant to corporate reorganizations. See 15 U.S.C. $\$ \$ 77 \mathrm{c}(9),(10)$, and $77 \mathrm{~d}$ (1958).

14. A registration statement is generally required to be in effect with the SEC prior to sales involving the mails or the channels of interstate commerce which effectuate the initial distribution of a security to investors. 15 U.S.C. $\$ 77 \mathrm{e}(\mathrm{a})$. This document must contain, inter alia, detailed information about the financial status of the corporation and the purpose for which the issue is being floated. See 15 U.S.C. $\$ \$ 77 \mathrm{~g}, 77 \mathrm{aa}$ (Schedule A).

After the issuer files the registration statement, the SEC examines it for deficiencies and irregularities, and issues a stop order if it finds either. If no stop order is issued within twenty days after filing, the registration statement becomes effective. 15 U.S.C. $\S \S 77 f, 77 \mathrm{~h}, 77 \mathrm{i}$.

15. 15 U.S.C. $\$ 77$ (e) (b) (2) (1958). Again, the sale must involve some use of the mails or the channels of interstate commerce in order to constitute a violation. Liability is also incurred if any other prospectus in addition to the statutory prospectus is used. 15 U.S.C. $\$ 77 \mathrm{e}(\mathrm{b})(1)$. Furthermore, subsection (c) of $\S 77 \mathrm{e}$, adopted in 1954, makes unlawful offers to buy or to sell in the absence of a registration statement. 
this purpose, section 11 grants a cause of action to any person who acquires a security issued under a registration statement which "contained an untrue statement of a material fact or omitted to state a material fact required to be stated therein or necessary to make the statements therein not misleading ...."16 Under section 11 potentially liable parties include the issuer, its principal officers, its directors, experts to the extent of their contribution to the statement, underwriters, and all other persons required by the act to sign the statement. ${ }^{17}$

In contrast to sections 11 and $12(1)$, the section $12(2)$ civil action is directed toward protection of buyers in single transactions after the security has been initially distributed $;^{18}$ moreover, section $12(2)$ does not depend on violation of registration statement requirements or other detailed statutory or administrative innovations. ${ }^{19}$ Rather, section $12(2)$ allows the buyer to sue his immediate seller ${ }^{20}$ for rescission, or damages when the buyer has disposed of the security, if the vendor sold him the security by means of any prospectus or oral communication which contained "an untrue statement of a material fact or [an omission of] a material fact necessary in order to make the statements, in the light of the circumstances under which they were made, not misleading . . ..21 Despite its broadness of language, section 12(2) does not reach the great majority of sales made on exchanges or over-the-counter mar-

16. 15 U.S.C. $\$ 77 k(a)$ (1958).

17. Ibid.

18. Section $12(2)$ is not phrased in terms that exclude misstatements or omissions in prospectuses used in sales involving the initial distribution; but $\S 12(2)$ does not augment the sections that already apply to this situation. Where the plaintiff has both a $\S 12(1)$ and a $\S 12(2)$ action, the former section will nearly always be invoked, since under $\S 12(1)$ he has to prove only that no registration statement is in effect or that the prospectus he received did not conform in every detail with the registration statement, whereas under $\$ 12(2)$ he must prove a misstatement or omission of a material fact in the prospectus. Where the plaintiff has both a $\S 11$ and a $\S 12(2)$ action and the defendant is the issuer, the $\S 11$ action is more advantageous to the plaintiff, because it is not subject to the defense of a lack of actual or constructive knowledge of the misrepresentation, as would be an action under $\$ 12(2)$. Where other defendants potentially liable under either section are involved, the plaintiff's burdens are substantially the same under $\$ \S 11$ and 12(2): he must prove a misstatement or omission of a material fact in the registration statement $(\S 11)$ or in the prospectus he received ( $\$ 12[2]$ ), and in both actions he is subject to the innocent misrepresentation defense.

Section 12(1) exempts dealers selling the securities more than 40 days after the initial public offering, and $\$ 11$ exempts all dealers; insofar as these parties can be reached as sellers under $\$ 12(2)$, there may be exceptional cases in which $\S 12(2)$ will be employed in an action against persons in the chain of initial distribution.

19. See notes $14 \& 15$ supra and accompanying text.

20. This requirement of privity is tempered by $\$ 15$ of the Act, 15 U.S.C. $\$ 770$ (1958), which imposes liability on parties in a position of control over persons primarily liable.

21. 15 U.S.C. $\S 77 l(2)$ (1958). However, if the buyer knew of the defect when he acquired the security, his action fails. Ibid. As with $\S 12(1)$, the sale must involve some use of the mails or the channels of interstate commerce in order to constitute a violation. 
kets, ${ }^{22}$ because of the infrequent use of a prospectus by sellers in these transactions, and because of the factual difficulty in establishing who the "seller" was. ${ }^{23}$

In lawsuits under these three sections of the Securities Act defendants have sought to interpose defenses based on the plaintiff's conduct after he has learned of the violation and on the defendant's detrimental reliance upon such conduct. ${ }^{24}$ The types of conduct alleged in such defenses may involve, ${ }^{25}$ inter alia: (1) laches, in which the plaintiff waited a considerable length of time after discovery of the violation before bringing suit; ${ }^{28}$ (2) waiver, in which the plaintiff intentionally relinquished his claim or used it as a lever to gain other concessions ${ }^{27}$ (3) estoppel, in which the plaintiff: participated with the defendant in issuing the faulty registration statement or prospectus; or participated in the affairs of the business - all the way from voting, ${ }^{28}$ giving proxies, ${ }^{29}$ and accepting dividends ${ }^{30}$ to accepting an officership or directorship, $^{31}$ and actually assuming control of the corporation $;^{32}$ or made additional payments on the purchase price after learning of the violation; or refused an offer of rescission made after both parties were informed of the violation and the available cause of action..$^{33}$

The Securities Act does not explicitly state whether these defenses can be used in actions under the civil liabilities sections. The legislative history, moreover, contains no evidence of congressional intent on the precise issue. ${ }^{34}$

22. The Securities Exchange Act of 1934, 48 Stat. 881 (1934), 15 U.S.C. §§ 78a$78 \mathrm{hh}$ (1958), is the major federal source of regulation of these transactions.

23. However, brokers are liable as sellers in transactions outside the exchange or counter markets. Cady v. Murphy, 113 F.2d 988 (1st Cir. 1940).

24. These assertions might also be used by a plaintiff-creditor suing the stockholders of the debtor corporation on their unfulfilled stock pledges, when the defendants use as a defense the invalidity of the agreement to buy stock.

25. Not all of these situations have arisen under the Securities Act, but in view of Blue Sky and other securities litigation, it is not unrealistic to anticipate their use.

26. Royal Air Properties, Inc. v. Smith, 312 F.2d 210 (9th Cir. 1962) ; Straley v. Universal Uranium \& Milling Corp., 289 F.2d 370 (9th Cir. 1961) ; Carr v. Warner, 137 F. Supp. 611 (D. Mass. 1955) ; Bunge v. Kirchhoff, 251 Ill. App. 119, 126 (1928).

27. Wilko v. Swan, 346 U.S. 427 (1953) ; Royal Air Properties, Inc. v. Smith, supra note 26; Straley v. Universal Uranium \& Milling Corp., supra note 26; Carr v. Warner, supra note 26.

28. Kaye v. Sunbeam Quarries Co., 258 Ky. 190, 79 S.W.2d 700 (1935).

29. Straley v. Universal Uranium \& Milling Corp., 289 F.2d 370 (9th Cir. 1961).

30. Farmers' Union Coop. Royalty Co. v. Little, 182 Okla. 178, 77 P.2d 33 (1938).

31. Royal Air Properties, Inc. v. Smith, 312 F.2d 210 (9th Cir. 1962) ; Dale v. Rosenfeld, 229 F.2d 855, 859 (2d Cir. 1956).

32. This allegation was made in the Royal Air case, supra note 31, at 213.

33. See 3 Loss, Securities Regulation 1816 (2d ed. 1961).

34. See generally H.R. REP. No. 85, 73d Cong., 1st Sess. 1-9 (1933); Hearings on H.R. 4314 Before the House Committee on Interstate and Foreign Commerce, 73d Cong., 1st Sess. (1933); Hearings on S. 875 Before the Senate Committee on Banking and Currency, 73d Cong., 1st Sess. (1933) ; Conference H.R. Rep. No. 152, 73d Cong., 1st Sess. (1933) ; 77 Cong. REc. 2915-19 (1933) (remarks of Representative Rayburn); id. at 2926-27 (remarks of Representative Kelly) ; id. at 2912 (remarks of Representative Mapes). 
However, the policy of the act and the manner in which it is implemented provide a more fruitful basis for interpreting the statute. The basic strategy of the act is to foster informed investing by compelling disclosure of information through the use of deterrent civil actions. Allowance of the defenses of estoppel, waiver, and laches may in some cases lessen the plaintiff's chances of recovery, and, by increasing the frequency of successful defenses, tend to impair the deterrent function of the sections. To the extent that deterrence is in fact lessened, allowance of the defenses may be incompatible with the main goal of the act. On the other hand, the in terrorem effect was not intended to apply with the pervasiveness of poison gas. Deterrence is tempered in the act itself with defenses and limitations ${ }^{35}$ which reflect a desire to retain some of the remedial aspects - i.e., a primary concern for redress of harm already incurred rather than for the prevention of future violations through inculcation of fear - characteristic of civil actions. Moreover, in a civil suit, it traditionally has been thought unfair to allow a plaintiff to recover in spite of his actions inconsistent with the suit, where such actions were justifiably and detrimentally relied upon by the defendant. ${ }^{36}$

A solution to the question of whether the defenses of estoppel, laches, and waiver should be permitted may be found in an analysis of the civil liability sections in light of the existing tension between the deterrent and remedial policies embodied in the Act.

The strict liability under section $12(1)$ is one expression of the deterrent nature of the civil liability provisions of the act. In a section $12(1)$ suit, the major elements of the plaintiff's case are established by proof that the defendant sold the securities to him by the use of the mails or of some means of interstate transportation or communication, either in the absence of a registration statement or without providing the plaintiff-buyer with a prospectus duplicating the registration statement. ${ }^{37}$ The plaintiff need not prove that he relied upon, or that his damages were caused by, the seller's violation of the section. The defendant's intent and knowledge of the violation are irrelevant, ${ }^{38}$ as is an assertion by a corporation that the acts resulting in liability were ultra vires the corporation. ${ }^{39}$ The only way the defendant can escape liability is to show that the sale of the particular security or transaction was exempted from the coverage of section $12(1) .{ }^{40}$

35. E.g., the short statute of limitations, discussed at note 73 infra and accompanying text, and the affirmative defenses under $\S 11$, at notes $41-43$ infra and accompanying text.

36. See, c.g., 3 Pomeroy, Equity Jurisprudence 180 (5th ed. 1941) and cases cited.

37. See text of $\$ \S 5$ and 12 of the Act, 15 U.S.C. $\$ \S 77 \mathrm{e}, 77 l$ (1958), and notes 14 and 15 supra.

Two other elements of the plaintiff's case are: his compliance with the statute of limitations, Newberg v. American Dryer Corp., 195 F. Supp. 345 (E.D. Pa. 1961), and, where rescission is sought, his compliance with the tender requirement.

As with $\S 12(2)$, the privity requirement under $\S 12(1)$ is tempered by $\S 15$ of the act, which extends liability to persons in control of the seller. See 15 U.S.C. $\$ 770$ (1958).

38. 3 Loss, Securities Regulation 1693 (2d ed. 1961).

39. Ibid.

40. See note 13 supra. 
The section 11 action also places few obstacles in the way of a plaintiff's recovery and, thus, may indicate a primary concern for deterrence. Under section 11 the plaintiff need prove only a misstatement or omission in the registration statement. He need not furnish proof of scienter, of privity between himself and the defendants, of actual reliance upon the untruth or omission, or of a causal relationship between the defect and his loss. However, unlike the section 12(1) defendant, the section 11 defendant is given several affirmative defenses. Damages are reduced to the extent that the defendant can prove that they did not result from the violation. ${ }^{41}$ In addition, the defendant can prevail upon a showing that the plaintiff knew of the untruth or omission at the time he acquired the security, ${ }^{42}$ and any defendant other than the issuer can escape liability if he can prove that he had, after reasonable investigation, reasonable ground to believe and actually believed that the statements were true and that there were no misleading omissions. ${ }^{43}$ Although these defenses may inject an element of concern for remedy not present in section $12(1)$, the very difficult proof problems which the defenses entail imply that they were not expected to remove the deterrent function from section 11.

In addition to the deterrent aspects apparent on the face of sections 11 and $12(1)$, the fact that these provisions interact to impose disclosure requirements on the initial distribution of securities lends support to the inference that deterrence was a central goal of these sections. An initial issuance and distribution of a block of securities will generally have greater public impact, in terms of both the number of people affected and the amount of money involved, than an isolated sale subsequent to the initial distribution. ${ }^{44}$ Congress, perhaps in recognition of this greater impact, imposed a requirement of administrative evaluation of the information thought necessary to assure informed investing before the issue is distributed $;^{45}$ the SEC procedure created in the act was thus designed to prevent harm to investors before it occurred. Section $12(1)$, insofar as it coerces compliance with this requirement of filing information with the SEC, is concerned with deterrence rather than with the redress of damages already incurred. Moreover, congressional concern for full disclosure during the initial distribution extended beyond requiring registra-

41. 15 U.S.C. $\$ 77 \mathrm{k}(\mathrm{e})(1958)$.

42. 15 U.S.C. $\$ 77 \mathrm{k}$ (a) (1958).

43. 15 U.S.C. $\$ 77 \mathrm{k}(\mathrm{b})(3)(1958)$.

44. The impact of $\S \S 11$ and $12(1)$ also seems broader in terms of the number of transactions affected. Although $\S 12(2)$ does not generally reach over-the-counter and exchange transactions (see text accompanying notes $22 \& 23$ supra), securities traded on exchanges and over-the-counter markets will, in all likelihood, have been issued and distributed under circumstances that involve $\$ \S 11$ and $12(1)$, and the price of such securities will be affected by the information disclosed in the registration statement and the statutory prospectus.

45. See note 14 supra. The Commission is empowered to seek injunctions against violations of the act $(\S 77 t)$, and criminal penalties may be imposed for willful violations $(\S 77 x)$. 
tion with the SEC. Section 12(1) was also designed to compel dissemination of the information in the registration statement to all purchasers in the chain of initial distribution through a prospectus identical to the registration statement. Section 11 was devised to assure the accuracy and completeness of this information. This prospectus "conditions" the market by supplying to the securities industry and the investing public basic facts on which investment decisions are, in large part, founded; because of this conditioning effect, the prospectus plays a major role in determining the marketability of the security. ${ }^{46}$ It thus appears that Congress, aware of the great impact of the prospectus on the securities market, intended section 11 to operate in a preventive fashion - to secure complete and honest disclosure by increasing the possibility of successful civil suits - rather than to cure the harm after it had occurred. In view of the importance placed on the deterrent nature of these sections, and in the absence of competing considerations, the defenses of waiver, estoppel, and laches should not be allowed. ${ }^{47}$

On the other hand, it could be argued that allowance of the defenses would not lessen the deterrent function of sections 11 and $12(1)$ : it might be unrealistic to expect an issuer or seller to violate the Act in the hope that his victims will shield him from liability by subsequently engaging in some conduct amounting to waiver, estoppel, or laches. 48 However, this argument overlooks the fact that the sections are as much concerned with creating a general climate of fear of the statutory civil actions as they are with deterring the individual who is consciously considering whether to comply with the act. More frequent success of defendants in these actions might well lead to a less forbidding atmosphere, and, to the extent this occurs, conscientious adherence to the disclosure requirements by the securities industry may be lessened. An additional argument could be made that the improvement of

46. This market conditioner concept is implicitly recognized in a 1934 amendment to $\$ 11$. It provides that if a year has elapsed since the effective date of the registration statement, and if the issuer has made generally available to the public an earnings statement covering that first year, any plaintiff acquiring his securities after the year must prove that he acquired the security in reliance upon the defective registration statement. 48 Stat. 907 (1934), 15 U.S.C. $\$ 77 \mathrm{k}$ (a) (1958). This is in contrast to a plaintiff who acquired his stock within the one year, who need not prove reliance.

This provision apparently is based on the assumption that the facts in the registration statement will be vital factors in establishing the market value of the securities for some time after the effective date, and that consequently there should be no necessity for proving reliance by the investor. After one year, however, it is assumed that the facts presented in the registration statement will be so out of date as not materially to affect the market value of the security and that an investor should be entitled to recover only if he can sustain the burden of proof that he was misled through actual reliance upon the registration statement.

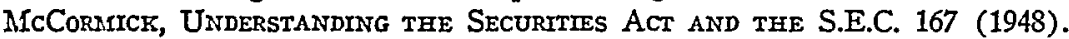

47. Thus, Straley v. Universal Uranium \& Milling Corp., 289 F.2d 370 (9th Cir. 1961 ), by allowing the defenses of estoppel and waiver in a $\$ 12(1)$ action, is inconsistent with the reasoning and conclusions expressed here. See also note 6 supra.

48. See Note, 62 Yale L.J. 985, 996 (1953). 
ethical standards in the industry ${ }^{49}$ and the dearth of lawsuits for registration statement violations ${ }^{50}$ indicate that a relaxation of the in terrorem effect would not hinder operation of the act. But this argument also seems shortsighted, since it ignores the possibility that the reason the industry is more ethical and few suits are brought is that the deterrent nature of the sections is operating as intended. 51

Significant differences between the sections concerned with initial distribution and section $12(2)$, which ordinarily applies to sales subsequent to initial distribution, suggest that in section $12(2)$ Congress was more concerned with providing a remedy for losses incurred and less concerned with in terrorem deterrence than in sections 11 and $12(1)$. Since section $12(2)$, in effect, applies only to individual sales after distribution, and since information misstated in a section 12(2) sale will not condition the general market for the securities, no overriding concern with a large impact on the public is involved in this section. Therefore, a de-emphasis of the deterrent function in section 12(2) would not have been expected to have the same broad economic implications as a lessening of deterrence in sections 11 and $12(1)$.

Unlike section 11 and 12(1) actions, which implement statutory innovations ${ }^{52}$ and a complex regulatory procedure, the section $12(2)$ action appears to be basically a statutory counterpart to common law rescission ${ }^{53}$ many elements of the causes of action are identical. ${ }^{54}$ The primarily remedial nature of common law rescission is demonstrated by its focus on making the plaintiff

49. See Loss, Foreword, Contemporary Problems in Securities Regulation, 45 VA. L. REv. 787 (1959). As early as 1945, the SEC felt that

New standards prevail in the business of inducing investors to part with their money. ... There now prevail new concepts of fair dealing, of adequate disclosure and of the duties of management and insiders. The general acceptance of these ethical standards by the business community is reflected not alone in the policies and outlook of those subject to the Commission's jurisdiction, but it is also evidenced in many respects in the practices of businesses not within the jurisdiction of the Commission.

10 S.E.C. ANn. REP. 8 (1945).

50. See 3 Loss, Securities Regulation 1684-89 (2d ed. 1961).

51. Moreover, derogation from congressional intent as expressed in the act on the basis of a supposed change in securities industry ethics would seem to be an improper method of statutory construction. Such changes in the basic design of the act should be the province of Congress; for a court to rewrite the act in such fashion would be a very transparent form of judicial legislation.

52. See note 14 supra and accompanying text.

53. Although the legislative history of $\S 12(2)$ is unclear, several commentators have made this inference. See, e.g., 3 Loss, Securities Regulation 1700 (2d ed. 1961); Bane, The Federal Securities Act of 1933, 14 B.U.L. Rev. 35, 42 (1934).

54. The common-law requirement that the plaintiff prove a misstatement or omission of a material fact was not changed by $\S 12(2)$. Neither action requires the plaintiff to prove a causal relationship between the misstatement and the decline in value of the security, and both actions bar the plaintiff's recovery if he knew of the misstatement or omission at the time he acquired the security.

Since the defenses of estoppel, waiver and laches were allowed at common law, the resemblance may imply that the defenses were not meant to be abrogated in $\S 12(2)$. 
whole by restoring the status quo, and by including the estoppel, waiver, and laches defenses, which permit courts to achieve equitable results by recognizing the defendant's detrimental reliance on the plaintiff's prior conduct inconsistent with the later desire to rescind.

The section 12(2) suit, however, differs in several respects from the rescission action at common law, and these deviations may reflect an effort to bolster the plaintiff's position. The question, then, is whether section $12(2)$ shifts the emphasis of the action from redress of damage to deterrence of harm to such an extent that allowing waiver, estoppel, and laches would be inconsistent with the policy of the section. The advantages given to the plaintiff in section 12(2) not available in the non-statutory action include a choice of federal or state jurisdiction, ${ }^{55}$ and, if federal jurisdiction is chosen, the rights to nationwide service of process and a broad choice of venue. ${ }^{56}$ The section $12(2)$ plaintiff is also given a choice of remedy - he may either tender the securities and demand return of the purchase price, or sue for damages representing his monetary loss - whereas in the rescission action tender is required. ${ }^{57}$ A third advantage under $12(2)$ is that the plaintiff need not prove his reliance on the misstatement or omission. ${ }^{58}$ On the other hand, the section 12(2) plaintiff is faced with a defense with which he was not confronted in the non-statutory action $:^{59}$ the defendant can prevail if he proves that "he did not know, and in the exercise of reasonable care could not have known, of [the] untruth or omission." 60 In addition, the short one year ${ }^{61}$ statute of limitations facing the plaintiff in a section 12(2) action was generally absent in the common-law action. In sum, the protection afforded plaintiffs by section $12(2)$ does not seem to be significantly greater than that given by common law rescission, and it may be inferred that no major shift in focus toward deterrence was intended in section $12(2)$.

Finally, the greater emphasis of section $12(2)$ on remedy rather than deterrence can also be seen by comparing the apparent concern for defendants in section 12(2) with that in sections 11 and 12(1). In section 12(2) defendants escape liability if they can show that the violation was neither intentional nor negligent. Under section 11 only defendants other than the issuer have this defense, and under section 12(1) no defendant can escape liability through such a showing. In these latter actions deterrence is furthered by holding defendants liable in spite of objections that the violation was innocently committed. The existence of the defense of innocent misrepresentation in section

55. 48 Stat. 86 (1933), as amended, 15 U.S.C. $\$ 77 \mathrm{v}$ (1958).

56. Ibid.

57. 5 Corbin, Contracts $\S 1116$ (1951); Shulman, Civil Liability and the Securities Act, 43 Y ALE L.J. 227, 244 (1933).

58. Shulman, supra note 57, at 247. Murphy v. Cady, 30 F. Supp. 466 (D. Me. 1939), aff'd, 113 F.2d 988 (1st Cir.), cert. denied, 311 U.S. 705 (1940).

59. See Shulman, supra note 57, at 243.

60. 15 U.S.C. $\$ 77 l(2)$ (1958).

61. See note 73 infra and accompanying text. 
12(2) removes this element of deterrence, and to this extent section $12(2)$ is more remedial in nature than sections 11 and $12(1)$.

In view of the primarily remedial rather than deterrent nature of section $12(2)$, allowance of the waiver, estoppel, and laches defenses appears to be in harmony with the policy of the section. ${ }^{62}$ However, this should not be taken to imply that the section is entirely without deterrent purpose. Section $12(2)$ is more than a simple codification of common law rescission, and although, in effect, it places less emphasis on deterrence than sections 11 and 12(1), the section is nevertheless an integral part of the statutory scheme designed to protect investors. In order to maintain this ambivalent statutory policy, a court should not relax the common-law requisites of the various defenses; such relaxation might well undercut the basic protective policy of the Act and thwart the subsidiary deterrent function of section $12(2)$.

For example, a court considering an estoppel defense should insist upon adequate proof that the plaintiff has made a representation, either by words or deeds, which would induce a reasonable man in the defendant's position to detrimentally rely on the representation, and which has in fact induced such reliance. ${ }^{63}$ One element of this defense has presented a recurring problem for courts and should be carefully considered in the 12(2) context: whether the collection of acts done and statements made by the plaintiff amounts to a representation sufficient to justify reliance by the defendant. The common-law and Blue Sky cases do not present a uniform or systematic answer to this question, partly because the answer must depend on many variable facts; a minor change in a fact situation could easily produce the opposite result. One situation in which the question of the sufficiency of the representation may arise is presented by those cases where estoppel is sought on the grounds that the plaintiff, after he had learned of the violation, participated in the affairs of the corporation whose securities he bought. At one end of the spectrum, the buyer may have participated in the affairs of the business rather insignificantly by actions such as giving proxies, accepting dividends, or attending meetings to vote his stock when his holdings did not affect control of the corporation. ${ }^{64}$ In the ordinary case, such acts would not constitute a representation that the plaintiff-buyer was relinquishing his right to sue, and reliance on such acts would not be justified. ${ }^{65}$ At the other end of the spectrum, however, the buyer's participation in the business may have been so great that he achieved control of the corporation. ${ }^{66}$ In this case the representation, if detrimentally relied upon, would appear to be sufficient to estop the plaintiff. For

62. See text following note 54 supra. This conclusion is apparently shared by Professor Loss, who assumes that, at least where the plaintiff's action is for rescission rather than damages, the defenses are carried over into $\$ 12(2) .3$ Loss, SECURITIEs REgulatron 1702 (2d ed. 1961).

63. 3 POMERoY, EQUTTY JURISPRUdENCE 191-92 (5th ed. 1941).

64. See notes $28-30$ supra and accompanying text.

65. See, e.g., Dale v. Rosenfeld, 229 F.2d 855,859 (2d Cir. 1956), and analogous Blue Sky cases cited in 3 Loss, Securities Regulation 1678 nn:236-37 (2d ed. 1961).

66. Cf. Royal Air Properties, Inc. v. Smith, 312 F.2d 210, 213 (9th Cir. 1962). 
cases between these two extremes, the almost infinite factual nuances preclude any generalizations about their outcome. ${ }^{67}$

As with estoppel, a court considering the waiver defense under section 12 (2) should not relax the common-law requisites of the defense ${ }^{68}-$ a voluntary and intentional relinquishment of a known and existing legal right or claim which either was given for a consideration or was given without consideration but did in fact induce detrimental reliance by the defendant. Thus, for example, if the investor, having told the seller of his intent to waive, later decided not to waive and informed the seller of this before the seller had detrimentally relied upon the previous statement, the requirements for waiver should not be deemed to have been satisfied.

Despite the theoretical applicability of the estoppel, waiver, and laches defenses in section 12(2) suits, other sections of the act may prevent their use. Although no other provision of the act appears to affect the availability of estoppel as a defense, section 14 does raise questions as to the waiver defense; it provides that

Any condition, stipulation, or provision binding any person acquiring any security to waive compliance with any provision of this subchapter or of the rules and regulations of the Commission shall be void. ${ }^{69}$

This section might seem, at first glance, to dispose of the question of the applicability of waiver as a defense. But the Supreme Court, applying section 14 to section $12(2)$ in Wilko v. Swan, ${ }^{70}$ distinguished between waivers before and after the existence of a controversy; it held that a stipulation made prior to the controversy would not be binding, but stated that a waiver after the buyer has been alerted to the precise illegality involved would not be objectionable, since the buyer would then be "able to judge the weight of the handicap the Securities Act places upon his adversary."' Similarly, the Court has applied this distinction to an anti-waiver clause in at least one other federal statute designed to protect those in an unequal bargaining position. ${ }^{\mathbf{2}}$ Therefore, section 14 does not seem to dispose of a consideration of the waiver defense based on the buyer's conduct after he learns of his right to bring suit.

Unlike the waiver and estoppel defenses, the laches defense in section 12(2) actions appears to be barred by a separate provision of the act. Section 13 of

67. In each case, however, the trier of fact should insist upon clear proof of acts sufficient to constitute a representation. See text following note 62 supra.

68. As modified by $\S 14$ of the act. See notes $69-71$ infra and accompanying text.

69. 48 Stat. 84 (1933), as amended, 15 U.S.C. \$ 77n (1958).

70. 346 U.S. 427 (1953).

71. Id. at 435.

72. Callen v. Pennsylvania R.R., 332 U.S. 625, 630-31 (1948) (anti-waiver clause of the Federal Employers' Liability Act); see also Reader v. Hirsch \& Co., 197 F. Supp. 111, 116-17 (S.D.N.Y. 1961), where the court, construing the anti-waiver clause of the Securities Exchange Act, did not pass on the validity of a waiver after the dispute had come into existence, but pointed out that the arguments and considerations invalidating a waiver before the existence of a controversy are not present in the case of a waiver of an existing claim. The distinction is also urged in Note, Enforceability of Arbitration Agreenents in Fraud Actions under the Securities Act, 62 YALE L.J. 985, 994-96 (1953). 
the act imposes a very short statute of limitations on section 12(2) actions the plaintiff must bring suit within one year after his actual or constructive discovery of the misstatement or omission, and in no event may he bring suit if three years have elapsed since the sale. ${ }^{73}$ One function of the laches defense at common law was to impose a temporal limitation on the life of a cause of action to which no statute of limitations applied; frequently the basis of the defense was the plaintiff's unconscionable delay in bringing suit. And in actions governed by a statute of limitations running from the time of the violation, laches was often used to prevent unconscionable delay after the plaintiff had knowledge of the violation. ${ }^{74}$ Both the laches defense, when used in suits for which the statute of limitations is measured from the time of violation, and the Securities Act device of measuring the statute of limitations from the date of plaintiff's knowledge of the violation share at least the one common function of preventing the plaintiff's unconscionable delay in bringing suit. ${ }^{75}$ Thus Congress appears to have substituted the one year limit for the unconscionable delay standard, and the laches defense should not be allowed in the section $12(2)$ suit. ${ }^{76}$ Moreover, the very fact of a short one year statute of

73. 48 Stat. 84 (1933) (amended by 48 Stat. 908 (1934), as amended, 15 U.S.C. $\$ 77 \mathrm{~m}(1958))$. As originally enacted, the limitation was two years from actual or constructive knowledge of the defect, and there was no absolute limit, three years or otherwise, measured from the date of sale. The original limitations on $\$ 11$ actions were two years from actual or constructive knowledge, and no more than ten years after the security was first offered to the public; for $\$ 12(1)$, two years from the date of sale, and the same ten year limit. The 1934 amendment shortened the periods for both actions to one and three years, respectively.

The changes of the statute of limitations appear to have been a concession to the securities industry, which feared the harshness of the act and clamored for mitigation. See Wall Street Journal, Oct. 31, 1933, p. 1, col. 4; Dean, Twenty-Five Years of Federal Securrities Regulation by the Securities and Exchange Commission, 59 Colurr. L. REv. 697, 713-14 (1959). See also McCorMICK, Understanding the Securities Act ANd THE S.E.C. 184 (1948), where the reasons for the shortening are believed to be a fear of strike suits, and a recognition that the longer periods are unnecessary for the protection of the legitimate investor.

74. See 3 PoMreroy, EQuity JuRISpRUdence $\S 917$ (5th ed. 1941).

75. The inconsistency of allowing the laches defense to cut short a statute of limitations measured from the time of knowledge has been recognized by courts outside the context of the Securities Act. See, e.g., Victor Oil Co. v. Drum, 184 Cal. 226, 242, 193 Pac. 243, 250 (1920) ; Estudillo v. Security Loan \& Trust Co., 149 Cal. 556, 565, 87 Pac. 19,23 (1906).

76. Of necessity this implies that the plaintiff gets a "free ride" from the time he learns of the violation until the statutory period runs out (i.e., if the value of the security declines he can still get back the purchase price, and if it increases in spite of the violation, he will keep the security). This free ride may be less than a year, however, if his actual or constructive knowledge of the violation occurred more than two years after the sale. Moreover, it is unlikely that any plaintiff would be motivated to sue until the value of the stock decreases, even in the absence of any intent to get a free ride on the market; disallowing a plaintiff's recovery by use of the laches defense would bar recovery by numerous plaintiffs. This would seem contrary to Congress' intent to protect misinformed investors. See text following note 62 supra. 
limitations may imply that the laches defense is unavailable under the Act. ${ }^{77}$ Of course, the laches defense only goes to the question of the time factor; insofar as the delay is accompanied by other conduct inconsistent with the assertion of the plaintiff's section $12(2)$ rights, questions of waiver and estoppel are involved.

The question of the applicability of the estoppel, waiver, and laches defenses has also arisen in the context of the increasingly frequent use of SEC rule $10 \mathrm{~b}-5$ by plaintiffs to redress grievances similar to those covered by sections $11,12(1)$, and $12(2)$ of the Securities Act of 1933. The relevant portions of rule $10 \mathrm{~b}-5$ declare unlawful the use by any person of the mails or the channels of interstate commerce to make an untrue statement or a misleading omission of a material fact. ${ }^{78}$ While rule $10 \mathrm{~b}-5$ does not explicitly provide a remedy, in order to make the rule effective courts have inferred a private civil action for violation of its provisions. ${ }^{79} \mathrm{~A}$ basic problem posed by the judicial creation of the $10 \mathrm{~b}-5$ civil suit is raised by those cases wherein the operative facts appear to permit suit under either rule $10 \mathrm{~b}-5$ or one of the civil liability provisions of the 1933 act: is $10 \mathrm{~b}-5$ to be applied independently of the 1933 act, or is the rule to be read in conjunction with the act, so that $10 \mathrm{~b}-5$ plaintiffs will not be able to escape the limitations and defenses which would apply if the suit were brought under the corresponding section of the act? ${ }^{80}$ The more narrow question presented by this Note is whether the de-

77. See 3 Loss, Securities Regulation $1777 \&$ n.236 (2d ed. 1961).

78. The rule is drafted very broadly, and includes no reference to requirements of privity, reliance, causation, or scienter:

It shall be unlawful for any person, directly or indirectly, by the use of any means or instrumentality of interstate commerce, or of the mails, or of any facility of any national securities exchange,

(a) To employ any device, scheme or artifice to defraud,

(b) To make any untrue statement of a material fact or to omit to state a material fact necessary in order to make the statements made, in the light of the circumstances under which they were made, not misleading, or

(c) To engage in any act, practice, or course of business which operates or would operate as a fraud or deceit upon any person in connection with the purchase or sale of any security.

79. See, e.g., Fischman v. Raytheon Mfg. Co., 188 F.2d 783 (2d Cir. 1951); Kardon v. National Gypsum Co., 69 F. Supp. 512 (E.D. Pa. 1946).

80. Of the many cases wrestling with this problem, perhaps the most thoughtful consideration appears in Ellis v. Carter, 291 F.2d 270 (9th Cir. 1961). There the court, recognizing the anomaly of their decision, decided to allow the plaintiff-buyer to sue under rule 10b-5 free of the restrictions imposed by the 1933 Act:

While it assumes that Congress in 1934 undid what it carefully did in 1933, it avoids judicial rewriting of the 1934 Act to include procedural provisions which appear only in the 1933 Act.

Id. at 274. But compare Rosenberg v. Globe Aircraft Corp., 80 F. Supp. 123 (E.D. Pa. 1948), where the court stated that "it cannot be supposed that Congress intended to abolish these regulations and limitations [in $\S \S 11$ and 12] when it enacted Sec. 10 of the Act of 1934." Id. at 124. On the general lack of uniformity of courts regarding 10b-5, and the problems they face in applying it, see 3 Loss, Securities Regulation 1763-97 (2d ed. 1961). 
fenses of waiver, estoppel, and laches should apply to rule 10b-5 actions used as a substitute for civil liability suits under the 1933 act. If a court decides that rule $10 \mathrm{~b}-5$ should be read together with the particular section of the 1933 act for which it is being substituted, the common law defenses should, of course, apply to the same extent urged for that section. ${ }^{81}$ One exception in this across-the-board application of the defenses may occur in the case of the laches defense. There is no federal statute of limitations for $10 \mathrm{~b}-5$ actions, and most courts have applied the statute of limitations of the state in which the violation occurred. ${ }^{\mathrm{s} 2}$ This has meant that the statutes governing $10 \mathrm{~b}-5$ actions are invariably longer than the one year limitation under section 13, and often more than three years. ${ }^{83}$ If parity is desired between the two actions in this respect, the laches defense might be allowed in the $10 \mathrm{~b}-5$ suit to limit the time within which suit may be brought in order to coincide with the time limit under the corresponding section of the 1933 act.

However, rule $10 \mathrm{~b}-5$ may be read to give plaintiffs a remedy completely independent of the Securities Act. If the basis for the interpretation does not involve the deterrence-remedy analysis, the court may wish to deny or allow the defenses according to its reason for so construing the rule. ${ }^{84}$ If, however, the court has analyzed the rule in terms of a tension between deterrent and remedial functions, the problem of allowance of the defenses depends on which function is considered more central to the purpose of the rule, and whether allowance of the defenses is consistent with this purpose.

81. See text accompanying notes $47,62, \& 76$ supra.

82. For deceit, or breach of warranty, or whatever local statute of limitations seems most analogous to the case. See, e.g., Errion v. Connell, 236 F.2d 447, 455 (9th Cir. 1956); Tobacco and Allied Stocks, Inc. v. Transamerica Corp., 143 F. Supp. 323, 327-28 (D. Del. 1956).

83. See 3 Loss, Securities Regulation 1774 (2d ed. 1961), and cases cited in note 82 supra.

84. E.g., the decision may be based on reasoning like that in Ellis v. Carter, 291 F.2d 270 (9th Cir. 1961). 